\title{
Mevsimsellik ve Dindarlık İlişkisi
}

\author{
DOI: 10.26466/opus.669291
}

\section{Selahattin Yakut*}

*Dr. Öğretim Üyesi, Yozgat Bozok Üniversitesi İlahiyat Fakültesi, Felsefe ve Din Bilimleri Bölümü, Din Psikolojisi ABD, Yozgat / Türkiye

\section{Öz}

ORCID: 0000-0002-3189-2123

Çevresiyle etkileşimi doğum öncesinden başlayan ve yaşamı boyunca devam eden insan, bu etkileşimin pozitif I negatif yönü, tonu ve şiddeti ölçüsünde psiko-sosyal, bilişsel ve duygusal dünyası şekillenen sosyal bir varlıktır. Insanın etkileşim içerisinde bulunduğu çevre kavramı, sınırların kesin olarak belirlemenin mümkün olmadığ bir esnekliğe sahiptir. Bu bağlamda yaşanılan mevsimleri de çevre kavramı içerisinde değerlendirmek ve insanın psiko-sosyal dünyasını etkileme potansiyeline atıfta bulunmak mümkündür. Bu anlamda psikosomatik (beden sağglı̆g - ruh sağglığı etkileşimi) bir yaklaşımla insanın fizyolojik ve psikolojik sağllğını etkileme potansiyeline sahip iki kavram olarak mevsimsellik ile dindarlık ilişkisini çeşitli değişkenler açısından değerlendirme amacı taşıyan bu çalışmanın örneklem grubu Polatli'da çeşitli yaş ve mesleklerden seçkisiz örneklem yoluyla seçilen 62 (41.89) bayan ve 86 (\%58.11) erkek olmak üzere toplam 148 kişiden oluşmaktadır. "Kişisel Bilgi Formu", "Mevsimsellik Ölçeği" ile "Dindarlık Envanteri" kullanılarak elde edilen verilerin SPSS programında frekans, aritmetik ortalama, standart sapma; çarpıklık ve basıklık değerlerinin normal dağılım puan aralı̆̆ında olması üzerine parametrik testlerden t-testi, Pearson korelasyon, Anova ve Scheffe testi anlamlılık düzeyi $p<0,05$ kabul edilerek uygulanmış ve şu sonuçlara ulaşılmıştır: Örneklemin mevsimsellik puanının orta düzeyde olduğu, dindarlı puanının ise yüksek düzeye yakın bir ortalamaya sahip olduğu; mevsimsellik ile dindarlığın duygu boyutu arasında anlamlı pozitif yönlü zayıf düzeyde ilişki bulunduğu; yaş değişkeninin mevsimsellik puanlarn üzerinde oluşturduğu farkın ise istatistiksel açıdan anlamlı olduğu tespit edilmiş̧ir.

Anahtar Kelimeler: Din psikolojisi, Mevsimsellik, din, dindarlik, dindarlik boyutları 


\title{
Relationship Between Seasonality And Piety
}

\begin{abstract}
The human being whose interaction with his environment begins before birth and continues throughout his life is a social entity whose psycho-social, cognitive and emotional world is shaped in terms of the positive / negative aspect, tone and intensity of this interaction. The concept of the environment in which man interacts has a flexibility in which it is not possible to determine its limits with certainty. In this context, it is possible to evaluate the seasons experienced within the concept of Environment and to refer to the potential to affect the psycho-social world of human beings. In this sense, psychosomatic (physical health - mental health Interaction) approach that have the potential to affect the health of people with physiological and psychological relationship between two concepts as religiosity in terms of the evaluation of several variables with seasonality, with the aim of this study was the sample group selected through sampling of various ages and professions in Polatl seckisiz 62 (41.89) miss and 86 (\%58.11) consists of persons for a total of 148 male. "Personal information form", "Scale Seasonality" and "Piety" Inventory data obtained in SPSS by using frequency, arithmetic mean, standard deviation; skewness and kurtosis values for normal distribution be in the range of points on parametric tests, $t$-test, Pearson correlation, Anova, and Scheffe test significance level of $P<0.05$ applied to be accepted, and the following conclusions were reached: It was determined that the seasonality score of the sample was moderate, the religiosity score was close to high, there was a significant positive-directional weak relationship between seasonality and the emotion dimension of religiosity, and the difference between the age variable and seasonality scores was statistically significant.
\end{abstract}

Keywords: Religious psychology, Seasonality, religion, piety, dimensions of piety 


\section{Giriş}

İnsanın psikolojik yapısı, doğumla sahip olduğu genetik kodların çevreyle etkileşimi sonucu adeta ilmek ilmek örülmektedir. Her ne kadar genetik yapımızın programladığı bir robot değilsek de genetik yapımızdan tamamen bağımsız olmadığımız da bilinen bir gerçekliktir (Hamer ve Copeland,1999). Bu anlamda insanın duygu, düşünce, bilinç, biliş vb. tüm boyutlarını genetik yapısı ve etkileşim içerisinde bulunduğu çevrenin kazanımları bağlamında değerlendirmek mümkündür. Çok boyutlu bir varlık olarak insanın evrende, kendi dışındaki her detaydan etkilenmesi büyük bir olasılık olarak karşımızda durmaktadır. İnsanın psikolojik dünyasına ait anlamlandırma tarayıcıları, çevrenin tüm uyarıcılarını olumlu yada olumsuz olarak kodlarlar. Bu kodların zihinsel olarak çözümlenmesine ve anlamlandırılmasına bağlı olarak insanın duygu ve düşünce dünyası da şekillenmiş olur. Bu bağlamda çevremizdeki tüm canlıların, nesnelerin; yaşanılan olayların; renklerin (Ann,2002; Ahbap,2014); doğal peyzajın (Özgüner,2004), mekanların (Kutlu, 2018) ve içinde bulunulan mevsimlerin (Ekinci, Okanlı ve Gözüağca 2005; Bakım vd. 2013; Kiremitçi ve Coşkun, 2017) insanın psiko-sosyal dünyasında pozitif yada negatif anlamlı bir karşllı̆ının olduğunu söylemek mümkündür. Özellikle mevsimlerin iklim, yükselti, bitki örtüsü, kuraklık gibi fizyolojik sağlığımızı direkt etkileyen unsurlarda belirleyici olması ve bu unsurların da sadece fizyolojik yapımızla sınırlı kalmadığını varsaydığımız etkileri, aslında çevrenin tüm boyutlarıyla insan üzerindeki potansiyeline bir göndermedir. Zira insanın ruhsal ve bedensel yapısını birbirinden bağımsız düşünmek neredeyse imkansızdır (Akın,2014; Belhi, 2018).

Mevsimlerin etkileri bağlamında tüm mevsimler için çatı bir kavram olarak kullanabileceğimiz ve mevsimlerin çevresel faktörlerde meydana getirdiği değişim (Bakım, Karaahmet, Altınbaş ve Oral, 2013) ve ruhsal durum, enerji, uyku süresi, iştah, yemek seçimi veya sosyal faaliyetleri etkileme derecesi olarak (Yöney vd., 1995) tanımlanan mevsimsellik; etkileri bakımindan turizm (Aydemir \& Şenerol, 2014), ticaret (Polat ve Uslu,2010), tarım (Bayraç ve Doğan,2016), ulaşım (Çalışkan vd., 2017) ağırlıklı bir kavram olarak değerlendirilmiş olsa da; insanlarda psikolojik semptomlara neden olduğu tespitinden (Kiremitçi Canı̈̈z ve Coşkun,2018) hareketle psikolojik bir karşıllğının bulunduğunu da söylemek mümkündür. Bu bağlamda 
mevsimsel değişimlerin kişileri psikolojik yönden etkilediği ön kabulünden hareketle, mevsimlere bağlı olarak görülen hava koşullarındaki değişimlerin duygu ve düşünce dünyasındaki olumlu / olumsuz yansımalarının anlamlandırılması bir problem olarak karşımızda durmaktadır. Mevsimselliğin; ümitsizlik, karamsarlık, beslenme sorunları, uykusuzluk, asabiyet, motivasyon kaybı, yorgunluk, ilgisizlik, anksiyete, intihar eğilimi (Simrén ve ark., 2002; APA, 2013); depresyon (Ekinci, Okanlı ve Gözüağca, 2005); öznel iyi oluş (Kiremitçi Canıöz ve Coşkun,2018), bibolar duygudurum bozukluğu (Dağdeviren,1996; Özdemir,2018) gibi olumlu/olumsuz duygu durumlarıyla ilişkilendirilmesi, konunun insanın psikolojik ve fizyolojik yapısını etkileme boyutunu göstermesi açısından önemlidir. Bu durumu psikosomatik (beden sağlı̆̆ - ruh sağlı̆̆ etkileşimi) bir yaklaşımla çevresel uyarıcılara yüklenilen pozitif / negatif yönlü anlamın karşılı̆̆ının belirli boyutlarla sınırlı kalmaksızın organizmanın diğer tüm boyutlarında da kendini hissettirdiği ve bu anlamda insan yapısının bir bütünlük içerisinde bulunduğu şeklinde anlamlandırmak mümkündür (Okyayuz,1999).

İnsanın çok boyutlu yapısına atfen insanın çevresel etkileşimini belirli alanlarla sınırlandırmak mümkün değildir. Bu bağlamda insanın psikososyal dünyasının şekillenmesinde önemli etkenlerden birisi olarak da dindarlık olgusunun olduğu söylenilebilir (Pargament,2005). Tanrısal gerçekliğe bağlanma temasının yaşamın fonksiyonel bir göstergesi olarak kılınması (Subaşı, 2001) şeklinde anlamlandırabileceğimiz dindarlık; dinin müntesiplerini bedensel ve ruhsal bakımdan sağlıklı bireylere dönüştürme idealini sembolize eden bir olgudur (Ayten, 2013). Dindarlığın anlamlandırılması yanında hangi duygu, düşünce ve davranışın ne düzeyde dindarlık göstergesi olarak kabul edileceği; diğer bir ifadeyle dindarlığın sınırlarının nasıl belirleneceği de en az tanımlanması kadar problemli bir durumdur. Bu belirsizliğin giderilmesine yönelik dindarlı̆̆ın insanın içsel ve sosyal dünyasına yansıması bakımından inanç, ibadet, dini tecrübe (duygu), bilgi ve etki (Glock,1998, s.257) gibi çok boyutlu olarak değerlendirme yaklaşımları oldukça önemlidir. Dindarlığın boyutları; varlığından şüphe duyulmayan ilâhî bir varlığa gönülden teslim olmak, o inancın amaç ilkelerine inanmak (Mehmedoğlu,2004) inanç boyutu; tanriya bağlılık, itaat ve teslimiyetlerinin ifadesi olan ritüeller (Certel,2010) ibadet boyutu; Aşkın Varlık'a yönelik tecrübe edilmiş her türlü duygusal ilişki (Hökelekli, 1998) duygu (tecrübe) boyutu; dini hayatın sağlam temeller üzerine kurulmasını sağlayan dinin 
ilkelerini bilme durumu bilgi boyutu (Certel,2010) ve dindarlığın sosyal hayatını etkileme durumu olarak etki boyutu (Köktaş, 1993) şeklinde karşılanmaktadır. Bu bağlamda dindarlı̆̆ı tek bir bakış açısıyla değerlendirilemeyecek ölçüde farklı kanallardan beslenen ve içeriği duygusal olarak zenginleştirilebilen çok boyutlu şekilde kavramsallaştırmak mümkündür (Kurt, 2009).

Tanımı konusunda her ne kadar çok farklı yaklaşımlar olsa da (Erkol,2015 ) inancın yaşama yansıması şeklinde anlamlandırabileceğimiz dindarlık ( Yıldız,2001 ); her ânın kutsal varlık ile ilişkilendirilmesine ve bunun bir sonucu olarak yaşama anlam verilmesine katkı sağlamaktadır (Şentürk ve Yakut,2014). Yapılan araştırmalarda dindarlık ile öznel iyi oluş (Gencer, 2019), suçluluk (Kartopu ve Başkonut,2019), aktif yurttaşlık (Çetin vd.,2019), psikolojik iyi oluş (Karsl1,2019), mutluluk (Öztürk vd.,2017), şiddet (Yakut, 2012; Öğük, 2019), benlik saygisı (Koç,20009; Kımter,2011), empati (Özcan, 2016), yalnızlık ve yabancılaşma (Yakut,2016), rıh sağlığı (Baynal,2015), umut-iyimserlik (Kandemir, 2016), ölüm kaygısı ( Yıldız, 1998), depresyon (Ilgaz, 2015), stres (Tokur,2011), psikolojik sağlık (Gürsu,2011), yaşam doyumu (Temiz, 2019), narsisizm (Altun, 2015), hoşgörü (Yılmaz,2019) gibi insanın tüm yaşamını kuşatan ve onun hayat kalitesini direkt etkileme potansiyeli bulunan duygu durumlarıyla kurulan ilişki, dindarlığın insan açısindan önemini göstermektedir.

Bu bağlamda insan üzerindeki etkileri bakımından mevsimsellik ile dindarlık arasında nasıl bir ilişki olduğu ve bu iki olgunun insanı hangi yönde ne düzeyde etkiledikleri soruları insanı anlama amacı bakımından cevap bekleyen ve anlamlandırılması gereken sorulardır. Bu bakımdan psikosomatik (beden sağlığ - ruh sağlığı etkileşimi) bir yaklaşımla insanın fizyolojik ve ruhsal dünyasının birbirinden tamamen bağımsız olmadıkları ve birbirini etkiledikleri tespitinden hareketle genel olarak dindarlığın ve özel olarak dindarlığın boyutlarının mevsimsellik ile ilişki durumunu inceleyen bu çalışma, alanında bir ilk olma özelliği taşımaktadır. Buna ilaveten alanla ilgili yapılacak farklı çalışmalara esin kaynağı olması beklenmekte ve elde edilen verilerin alana sağlayacağı katkı önemli görülmektedir. 


\section{Araştırmanın Amact}

İnsanın psikososyal dünyasına üst düzey etkiye sahip iki olgu olarak konumlandırabileceğimiz mevsimsellik ve dindarlık arasındaki ilişkiyi tespit etme ve bu iki olgu düzeyini çeşitli değişkenler açısından inceleme amacı taşıyan araştırmamızda aşağıdaki sorulara cevap aranmıştır:

1-Mevsimsellik ile dindarlığın boyutları arasında ne tür bir ilişki söz konusudur?

2-Mevsimsellik ve dindarlık cinsiyete göre farklılaşmakta mıdır?

3-Mevsimsellik ve dindarlık yaşa göre farklılaşmakta mıdır?

4-Mevsimsellik ve dindarlık mesleğe göre farklılaşmakta mıdır?

5- Katılımcların mevsimsellik ve dindarlık-dindarlık boyutlarına dair genel düzeyleri nedir?

\section{Yöntem}

Araştırmada 2019 bahar döneminde Ankara'nın Polatlı İlçesi'nde seçkisiz olarak seçilen örneklemin mevsimsellik ve dindarlık düzeylerini çeşitli değişkenlere göre tespit etme amacı taşıyan tarama niteliğinde betimsel (survey) model benimsenmiştir. Araştırmanın bağımlı değişkeni mevsimsellik ve dindarlık düzeyi; bağımsız değişkenleri ise "cinsiyet, yaş ve meslek" olarak belirlenmiştir.

\section{Araştırma Grubunun Özellikleri}

148 kişiden oluşan ve seçkisiz olarak seçilen örneklemin yüzdelik dağılımları şu şekildedir:

Cinsiyet: Örneklemin \%41.89'u bayan, \%58.11'i erkektir.

Yaş: Örneklemin \%32.43'ü 18-30, \%26.35'i 31-44, \%20.95'i 45-55, \%20.27'si $56+$ yaş aralığındadır.

Meslek: Örneklemin \%25.68'i öğretmen, \%20.27'si memur, \%32.43'ü üniversite öğrencisi ve \%21.62'si esnaftır 
Örneklemin seçkisiz olarak seçilmesi, bu yöntemin evreni temsil etme özelliğinin güçlü olması ve temsil konusunda diğer yöntemlerden daha yüksek bir olasılığa sahip olması anlamına gelir (Karasar,2009).

\section{Veri Toplama Araçları}

Araştırma verileri örnekleme uygulanan "Kişisel Bilgi Formu", "Mevsimsellik Ölçeği" ve "Dindarlık Envanteri" uygulanarak elde edilmiştir.

Kişisel Bilgi Formu :Bu form kullanılarak katılımcıların demografik özellikleri "cinsiyet, yaş ve meslek" ile ilgili bilgiler toplanmıştır.

Mevsimsel Gidiş Değerlendirme Formu (MGDF): Araştırmada mevsimsel özelliklerin kişilerin fizyolojik ve psikososyal yaşantıları üzerindeki etkilerini inceleme amacıyla 1987'de Rosenthal ve arkadaşları tarafından geliştirilmiş ve Noyan ve arkadaşları (2000) tarafından Türkçeye uyarlanarak geçerlilik ve güvenilirlik çalışması yapılmış Mevsimsel Gidiş Değerlendirme Formu (Seasonal Pattern Questionary-SPAQ), kullanılmıştır. Bu bağlamda ölçeğin (uyku miktarı, sosyal yaşantı, duygu durum, kilo, iştah ve enerji düzeyi) maddelerinin Cronbach Alfa değeri .67 olarak; faktör analizinde $\mathrm{KMO}$ değeri .72, iç tutarlılık katsayısı ise .72 olarak tespit edilmiştir. (Noyan ve ark., 2000). Değişmez (0), Hafif (1), Ilımlı (2), Belirgin (3), Aşırı (4) olmak üzere beşli likert tipi ölçekten alınabilecek puanlar (0-24) aralığındadır. Ölçekten alınan puanın yüksekliği bireyin mevsimsellikten etkilenme şiddetini göstermektedir. Ölçeğin güvenilirliğine yönelik tarafımızca yapılan ölçümde Cronbach Alpha güvenirlik katsayısı da .71 olarak bulunmuştur. Bu katsayı değeri “0 - 40 : güvenilir değil 40 - 60 : düşük güvenilirlik, 60 - 80 : oldukça güvenilir, 80 - 100 : yüksek derecede güvenilir" (Özdamar, 2002) aralığına göre ölçeğin oldukça güvenilir olduğunu göstermektedir.

Dindarlık Ölçeği:Araştırmada Kula (2001) tarafından geliştirilmiş ve Aydemir (2008) tarafından geçerlik ve güvenirlik çalışması yapılmış, dindarlığın inanç, ibadet, duygu, bilgi ve etki boyutlarını ölçmeye yönelik 25 maddeden oluşan; "Kesinlikle Katıllyorum (5)", "Katıllyorum (4)", "Kararsızım (3)", “Katılmıyorum (2)”, “Kesinlikle Katılmıyorum (1)” şeklinde beşli likert tipi ölçek kullanılmıştır. Olumsuz maddeler 21 ve 22.tersten puanlanmıştır. 
Ölçekten 25-125 aralığında puan alınmaktadır. Puanın yüksekliği dindarlık düzeyinin yüksekliğini gösterir. Dindarlık envanteri üzerinde yapılan faktör analizi sonucunda faktör yüklerinin 0,30 ile 0,78 arasında değiştiği görülmüştür. Envanterin test-yarı test yöntemi ile kontrol edilmiş olan güvenirlik katsayısı .84, Cronbach Alpha güvenirlik katsayısı da .86 olarak hesaplanmıştır (Aydemir,2008). Ölçeğin güvenilirliğine yönelik tarafımızca yapılan ölçümde Cronbach Alpha güvenirlik katsayısı da .83 olarak bulunmuştur. Bu katsayı değeri “ 0 - 40 : güvenilir değil 40 - 60 : düşük güvenilirlik, 60 - 80 : oldukça güvenilir, 80 - 100 : yüksek derecede güvenilir" (Özdamar, 2002) aralığına göre ölçeğin yüksek derecede güvenilir olduğunu göstermektedir.

\section{İstatistiksel Analiz}

Verilerin analizinde SPSS 22.0 programın kullanılmıştır. Verilerin normal dağılım durumu skevness (çarpıklık) ve kurtosis (basıklık) değerleri esas alınmış (Kilne,2011) ve değerlendirme sonucunda mevsimsellik ölçeği ile dindarlık envanterinin skevness (çarpıklık) ve kurtosis (basıklık) verilerinin $(-2 /+2)$ arasında normal dağılım gösterdiği (George ve Mallery, 2010) tespitinden hareketle parametrik testlerden t-testi, Pearson korelasyon ve Anova testleri anlamlılık düzeyi $\mathrm{p}<0,05$ kabul edilerek uygulanmıştır. İlaveten tanımlayıcı istatistiklerden standart sapma, aritmetik ortalama ve frekans analizi kullanılmıştır.

Tablo 1. Normal dağılım sonuçlan

\begin{tabular}{lll}
\hline & Skewness (Çarpıklı) & Kurtosis (Basıklı) \\
\hline Mevsimsellik Ölçeği & $-0,648$ & 0,742 \\
\hline Dindarlı Ölçeği & $-0,914$ & 0,821 \\
\hline
\end{tabular}

\section{Bulgular}

Bölümde katılımcılara uygulanan "Mevsimsellik Ölçeği"nden ve “Dindarlık Envanteri"nden elde edilen verilerle ilgili istatistiksel işlemlere ve bu işlemler sonucu tespit edilen bulgularla ilgili yorumlara yer verilmiştir.

1. Araştırmanın birinci sorusu "Mevsimsellik ile dindarlık arasında ne tür bir ilişki söz konusudur?" şeklindedir. 
Tablo 2. Mevsimsellik- Dindarlık Boyutlan Arası Korelasyon Sonuçları

\begin{tabular}{lllllll}
\hline & & İnanç & Etki & Duygu & İbadet & Bilgi \\
\hline \multirow{3}{*}{ Mevsimsellik } & $\mathrm{r}$ & 0,02 & 0,15 & 0.28 & 0.09 & 0.07 \\
\cline { 2 - 7 } & $\mathrm{P}$ & 0.063 & 0.051 & $0.03^{*}$ & 0.053 & 0.059 \\
\cline { 2 - 7 } & Ort. & 3.18 & 3.73 & 4.38 & 3.68 & 2.98 \\
\hline
\end{tabular}

${ }^{*} p<0,05$ düzeyinde anlaml

Tablo 2'e bakıldığında mevsimsellik ile dindarlığın duygu boyutu arasinda ( $r=0.28 ; \mathrm{p}=0.03 ; \mathrm{p}<05)$ anlamlı pozitif yönlü zayıf bir ilişkinin olduğu tespit edilmiştir. Mevsimsellik ile dindarlığın duygu boyutu dışındaki diğer boyutları arasındaki korelasyon verileri ise istatistiksel açıdan anlamlı bulunmamıştır. Bu tespitler korelasyon analiz sonuçları yorumlanırken genellikle, (r) 0-0,24 arası doğrusal ilişki yok; 0,25-0,49 zayıf ilişki;0,50-0,69 arası orta düzey ilişki; 0,70-0,89 arası iyi/güçlü ilişki; 0,90 üzeri ise çok iyi/çok güçlü ilişki olduğu kabulünü (Kılıç,2018) yansıtmaktadır.

2. Araştırmanın ikinci sorusu "Mevsimsellik ve dindarlık cinsiyete göre farklılaşmakta mıdır?" şeklindedir.

Tablo 3: Cinsiyet Değişkenine Göre Mevsimsellik ve Dindarlık Puanlar için t- Testi Sonuçlar

\begin{tabular}{lllllll}
\hline & Cinsiyet & $\mathrm{N}$ & Ort. & SS & $\mathrm{t}$ & $\mathrm{P}$ \\
\hline \multirow{2}{*}{ Mevsimsellik } & Kadın & 62 & 58.91 & 1.83 & \multirow{2}{*}{3.742} & 0,61 \\
\cline { 2 - 5 } & Erkek & 86 & 56.88 & 1.22 & & \\
\hline \multirow{2}{*}{ Dindarlık } & Kadın & 62 & 48.53 & 1.09 & \multirow{2}{*}{4.78} & 0,74 \\
\cline { 2 - 5 } & Erkek & 86 & 49.05 & 1.03 & & \\
\hline
\end{tabular}

Tablo 3'e bakıldığında cinsiyet değişkenine göre bayan katılımcıların mevsimsellik puanlarının erkek katılımclardan yüksek olduğu ancak oluşan farkın istatistiksel açıdan (t(3.72; $\mathrm{p}=0.61 ; \mathrm{p}>0.05)$ anlamlı olmadı̆̆ görülmektedir. Diğer bir ifade ile bayanların mevsimlerden etkilenme düzeyi daha yüksektir ancak oluşan fark istatistiksel bakımdan anlamlılık düzeyine ulaşmamıştır.

Dindarlık-cinsiyet karşılaştırmasına baktığımızda ise erkek katılımcıların dindarlık puanlarının bayan katılımcların dindarlık puanlarından yüksek olduğu görülmektedir. Fakat oluşan fark yine istatistiksel açıdan anlamlı bulunmamıştır ( $(4.78) ; \mathrm{p}=0.74 ; \mathrm{p}>0.05)$.

3. Araştırmanın üçüncü sorusu "Mevsimsellik ve dindarlık yaşa göre farklılaşmakta mıdır?" ş̧eklindedir. 
Tablo 4. Yaş Değişkenine Göre Mevsimsellik ve Dindarlık Puanlan Arasındaki Anova Testi Sonuçlan

\begin{tabular}{|c|c|c|c|c|c|c|c|}
\hline & Yaş & $\mathrm{N}$ & Ort. & SS & $\mathrm{F}$ & $\mathrm{P}$ & $\begin{array}{l}\text { Farklar } \\
\text { (Scheffe testi) }\end{array}$ \\
\hline \multirow{4}{*}{ Mevsimsellik } & $18-30$ & 48 & 34.47 & 1.74 & \multirow[t]{4}{*}{3.042} & \multirow[t]{4}{*}{0.037} & \multirow[t]{4}{*}{$4-1,4-2,3-1$} \\
\hline & 31-44 & 39 & 35.84 & 1.34 & & & \\
\hline & $45-55$ & 31 & 36.42 & 1.36 & & & \\
\hline & $56+$ & 30 & 39.53 & 1.88 & & & \\
\hline \multirow{4}{*}{ Dindarlık } & $18-30$ & 48 & 26.89 & 1.34 & \multirow[t]{4}{*}{4.73} & \multirow[t]{4}{*}{0.079} & \\
\hline & 31-44 & 39 & 27.84 & 1.47 & & & \\
\hline & $45-55$ & 31 & 28.02 & 1.42 & & & \\
\hline & $56+$ & 30 & 28.37 & 1.28 & & & \\
\hline
\end{tabular}

Tablo 4 incelendiğinde yaş değişkenine göre yaşı (56) üzeri olanların en yüksek puana sahip oldukları ve oluşan farkın istatistiksel açıdan anlamlı olduğu görülmektedir. Tablodaki veriler ışığında genel olarak yaş ilerledikçe mevsimlerin insan üzerindeki etkisinin de anlamlı fark oluşturacak düzeyde arttı̆̆ söylenilebilir.

Yaş değişkenine göre dindarlık puanlarına bakıldığında yaş mevsimsellik karşılaştırmasında olduğu gibi yaşın ilerlemesine bağlı olarak dindarlık puanlarının arttığı, en yüksek dindarlık puanına 56 yaş üzeri katılımcıların sahip olduğu ancak oluşan farkın istatistiksel açıdan anlamlı olmadığı görülmektedir. Diğer bir ifade ile yaş dindarlık üzerinde anlamlı fark oluşturabilecek kuvvette değildir.

4. Araştırmanın dördüncü sorusu "Mevsimsellik ve dindarlık mesleğe göre farklılaşmakta mıdır?" şeklindedir.

Tablo 5. Meslek Değişkenine Göre Mevsimsellik ve Dindarlık Puanları Arasındaki Anova Testi Sonuçlan

\begin{tabular}{|c|c|c|c|c|c|c|}
\hline & Meslek & $\mathrm{N}$ & Ort. & SS & $\mathrm{F}$ & $\mathrm{P}$ \\
\hline \multirow{4}{*}{ Mevsimsellik } & Öğretmen & 38 & 31.54 & 1.21 & \multirow[t]{4}{*}{3.382} & \multirow[t]{4}{*}{0,58} \\
\hline & Memur & 30 & 31.89 & 1.20 & & \\
\hline & Üniv. Öğrencisi & 48 & 33.16 & 1.04 & & \\
\hline & Esnaf & 32 & 32.48 & 1.24 & & \\
\hline \multirow{4}{*}{ Dindarlık } & Öğretmen & 38 & 28.36 & 1.36 & \multirow[t]{4}{*}{5.438} & \multirow[t]{4}{*}{0,68} \\
\hline & Memur & 30 & 29.30 & 1.47 & & \\
\hline & Üniv. Öğrencisi & 48 & 27.87 & 1.41 & & \\
\hline & Esnaf & 32 & 30.48 & 1.23 & & \\
\hline
\end{tabular}

Tablo 5 incelendiğinde en yüksek mevsimsellik puanına üniversite öğrencilerinin sahip olduğu ancak meslekler arası oluşan mevsimsellik puan 
farkının istatistiksel açıdan anlamlı olmadığı görülmektedir (f (3.382; $p=0,58$; $\mathrm{p}>0,05)$. Diğer bir ifade ile meslek değişkeni mevsimsellik üzerinde anlam oluşturacak bir etkiye sahip değildir.

Meslek değişkeni ile dindarlık karşılaştırmasına baktığımızda ise en yüksek dindarlık puanına esnafların sahip olduğu ancak oluşan farkın anlamlı olmadığı görülmektedir ( $\mathrm{f}(5.438 ; \mathrm{p}=0,68 ; \mathrm{p}>0,05)$.

5. Araştırmanın beşinci sorusu "Katılımcların mevsimsellik ve dindarlık-dindarlık boyutlarına dair genel düzeyleri nedir" şeklindedir.

Tablo 6. Örneklemin Mevsimsellik ve Dindarlık Düzeyine İlişkin Tanımlayıı İstatistik

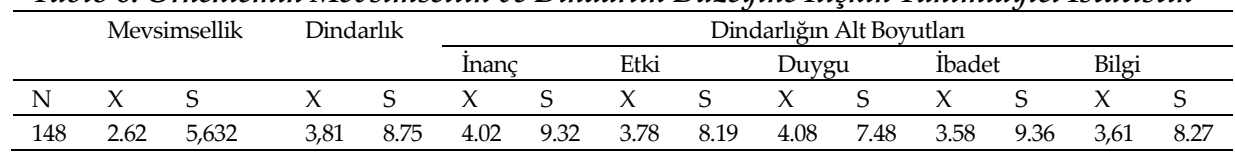

Tablo 6 incelendiğinde mevsimsellik puan ortalamasının likert tipi ölçekte en yüksek puan olan 4 üzerinden ılımlı (2) ile belirgin (3) arasında orta düzeyde olduğu $(X=2.62)$ görülmektedir. Dindarlık ölçeği ortalamasının ise likert tipi ölçekte en yüksek puan 5 üzerinden katılıyorum(4) ifadesine daha yakın olduğu yani orta düzeyin üzerinde yüksek düzeye yakın ( $X=3.81)$ olduğu söylenilebilir. Ayrıca dindarlık boyutlarının ortalama puanlarına bakıldığında örneklemin en yüksek ortalamaya duygu boyutunda, en düşük ortalamaya ise ibadet boyutunda sahip olduğu görülmektedir.

\section{Tartışma}

Araştırmamızda Ankara Polatlı İlçesi'nden çeşitli yaş ve meslekten seçkisiz olarak seçilen katılımcıların mevsimsellik-dindarlık düzeyleri arasındaki ilişkiyi ve mevsimsellik ile dindarlık puanları üzerinde "cinsiyet, yaş ve meslek" değişkenlerinin oluşturacağı farklar incelenmiş olup bulgularla ilgili tartışmalar şu şekildedir:

\section{Mevsimsellik-Dindarlık İlişkisi}

Araştırmamızda mevsimsellik ile dindarlığın duygu boyutu arasında $(\mathrm{r}=0.28 ; \mathrm{p}=0.03 ; \mathrm{p}<05)$ anlamlı pozitif yönlü zayıf bir ilişkinin olduğu tespit edilmiş̧ir. Mevsimsellik ile dindarlığın duygu boyutu dişındaki diğer bo- 
yutları arasındaki korelasyon verileri ise istatistiksel açıdan anlamlı bulunmamıştır. Çevre, insanın potansiyellerini değiştirme, dönüştürme ve geliştirme konusunda ve de yeni potansiyeller kazanma sürecinde insan üzerindeki en etkili faktörlerden birisi olarak kabul edilir. İnsan üzerindeki çevresel etkilerden birisi olarak da mevsimsel etkileri düşünmek mümkündür. Bu bağlamda araştırma sonucunu çok boyutlu bir varlık olan insanın çevresiyle girdiği etkileşim sürecinin en baskın şekilde kendisini duygusal alanda gösterdiği şeklinde değerlendirebiliriz. Ayrıca mevsimselliğin çevresel bir faktör olarak dindarlığın özellikle duygu boyutuyla anlamlı ilişki içerisinde bulunması, insanın tüm duygu durumlarında kullandığı psikolojik dilin aynı zamanda dinin duygu bağlamında kullandığı dilden farklı olmadığını göstermektedir. Diğer bir ifade ile dini duygunun dili ile potansiyel olarak insanda bulunan ve çevre etkileşimine bağlı olarak gelişen duygu durumunun dili aynıdır (Bovet,1958). Bu durumu özellikle çocukluk döneminde ebeveynle kurulan güvene dayalı ilişkinin şiddeti ve kalitesine bağlı olarak gelişen sevgi, saygı, bağlanma gibi duygusal yapının (Mehmedoğlu,2004) dini gelişim aşamalarında da kullanıldığı ve de insanın çevresel faktörlerden en fazla duygusal boyutta etkilendiği şeklinde değerlendirmek mümkündür. Buna ilaveten mevsimsellikle depresyon, stres, anksiyete, öznel iyi oluş, gibi duygusal yapıyla ilişkilendiren araştırmalarda (Simrén ve ark., 2002; APA, 2013; Ekinci ve ark, 2005; Kiremitçi Canı̈z \& Coşkun,2018; Dağdeviren,1996; Özdemir,2018) araştırma sonucumuzu dolaylı olarak desteklemektedir.

\section{Cinsiyet - Mevsimsellik ve Dindarlık}

Cinsiyet - Mevsimsellik: Cinsiyet değişkenine göre bayan katılımcıların mevsimsellik puanlarının erkek katılımclardan yüksek olduğu ancak oluşan farkın istatistiksel açıdan (t(3.72; $\mathrm{p}=0.61 ; \mathrm{p}>0.05)$ anlamlı olmadı̆̆ı görülmektedir. Diğer bir ifade ile bayanların mevsimlerden etkilenme düzeyi daha yüksektir ancak oluşan fark istatistiksel bakımdan anlamlılık düzeyine ulaşmamıştır. Konuyla ilgili (Atalar, 2012) ve (Yumuşak ve Boz 2013) tarafından yapılan araştırmalarda bayanların mevsimsellik puanlarının erkeklerden anlamlı fark oluşturacak şekilde yüksek olduğu sonucuna ulaşılmıştır. (Han vd.,2000) ve (Kiremitçi,2016) tarafından yapılan araştırmalarda ise araştırma sonucumuzla örtüşür şekilde bayanların mevsimsellik puanları- 
nın yüksek çımasına rağmen oluşan fark anlamlılık düzeyine ulaşmamıştır. Mevsimlerin etkilerini fizyolojik, psikolojik ve duygusal bağlamda değerlendirdiğimizde; bedensel güç ve fizyolojik bakımdan erkek kadar avantajlı olmayan (Taşkınöz, 2011) ve kaygı, stres, depresyon (Güvenç ve ark., 2004; Bal (2010), intihar eğilimi (Alptekin,2002) gibi duygu durumunu önceleyen hususlarda bayanların daha yoğun duygusallık yaşamaları; bayanlarin mevsimsellikten de fizyolojik ve duygusal anlamda daha fazla etkilendikleri sonucunu desteklemektedir. Ancak oluşan farkın anlamlı çıkmamasını mevsimselliğin cinsiyetle sınırlandırmanın mümkün olmayacağı bir etki çeşitliliğine sahip olduğu; cinsiyetin mevsimselliği kuşatacak ve anlamlı fark oluşturacak bir kuvvette değişken olmadığı şeklinde değerlendirmek mümkündür.

Cinsiyet - Dindarlık: Cinsiyet değişkenine göre erkek katılımcıların dindarlık puanlarının bayan katılımcların dindarlık puanlarından yüksek olduğu görülmektedir. Fakat oluşan fark istatistiksel açıdan anlamlı bulunmamıştır $(\mathrm{t}(4.78) ; \mathrm{p}=0.74 ; \mathrm{p}>0.05)$. Literatür incelendiğinde konuyla ilgili farklı sonuçlara ulaşıldığı görülmektedir. Karaca,2000; Atalay, 2005; Sevindik, 2015; Yakut, 2016; Yılmaz,2019 tarafindan yapılan araştırmalarda erkeklerin dindarlık düzeyinin yüksek olduğu; Yapıcı, 2007 / 2012; Ayten, 2009; Gürsu, 2011; Dağlı, 2010; Yüksel,2019 tarafından yapılan araştırmalarda ise bayanların dindarlık düzeyinin erkeklerin dindarlık düzeyinden daha yüksek olduğu sonuçlarına ulaşılmıştır. Şahin, 1999; Atalay, 2005; Elmas, 2017; Acar,2019; Aydın,2019 ise bizim araştırma sonucumuzu da destekler şekilde cinsiyetin dindarlık üzerinde anlamlı bir fark oluşturmadığı sonuçlarına ulaşmışlardır. Bu farklı sonuçlar dindarlığın sosyal, duygusal, psikolojik, kültürel vb. alanların birikimlerini kapsayan ve şekillenmesinde ailenin, çevrenin, arkadaş gruplarının, alınan eğitimin son derece önemli rol oynadığını ve de çok farklı kanallardan beslenen bir olgu olduğunu göstermektedir. Cinsiyet değişkeninin dindarlık üzerinde anlamlı fark oluşturmaması şeklindeki araştırma sonucumuzu ise dindarlığın cinsiyet kalıbına sığmayacak zenginlik ve çeşitlilikte bir yapıya sahip olduğu şeklinde değerlendirmek mümkündür. 


\section{Yaş - Mevsimsellik ve Dindarlık İlişkisi}

Yaş - Mevsimsellik: Yaş değişkenine göre yaşı (56) üzeri olanların en yüksek mevsimsellik puanına sahip oldukları ve oluşan farkın istatistiksel açıdan anlamlı olduğu görülmektedir. Tablodaki veriler ışığında genel olarak yaş ilerledikçe mevsimlerin insan üzerindeki etkisinin de arttı̆̆ ve en üst yaş kategorisine sahip olan katılımcılarda mevsimselliğin anlamlı fark oluş̧uracak etki düzeyine ulaştığı söylenilebilir. İnsan doğum öncesinden ölümüne kadar fizyolojik, psikolojik, sosyal, duygusal, zihinsel, dilsel, ahlaki, bilişsel gelişimi doğum öncesi, bebeklik, çocukluk, ergenlik, genç yetişkinlik, yetişkinlik ve yaşlılık olarak evreler bağlamında değerlendirilen ve incelenen bir varlıktır. Bu evrelerin genel olarak hız ve işlevleri üzerinde etkide bulunan faktörlerden birisi de yaştır (Santrock,2012). Yaşın ilerlemesine bağlı olarak denge ve güç kapasitesinin azalmasının bir yansıması biyolojik, psikolojik ve fizyolojik gerileme (Çekal,2006), kan basınc1, kolestrol, tansiyon, diyabet, kalp vb. sağlık sorunlarına yatkınlık ve bağışıklık sisteminin zayıflaması (Şentürk,2016) gibi ortaya çıkan problemler, kişiyi çevresel etkilere karşı savunmasız hale getirmektedir. Araştırma verilerinde de 56 yaş üzeri kattlımcıların mevsimsellik puanlarının oluşturduğu farkın anlamlı olması ve yaşın ilerlemesine bağlı olarak mevsimsellik puanlarındaki artış, yaşa bağlı olarak ortaya çıkan fizyolojik, biyolojik ve psikolojik anlamdaki gerilemenin bir göstergesi olarak değerlendirilebilir.

Yaş - Dindarlık: Yaş değişkenine göre dindarlık puanlarına bakıldığında 56 üstü yaşa sahip katılımcların dindarlık puanlarının diğerlerinden daha yüksek olduğu, yaş ilerledikçe dindarlık puanlarının arttığı ancak oluşan farkın anlamlı olmadığı görülmektedir. Konuyla ilgili Hökelekli, 2003; Aydemir, 2008; Yoğurtcu, 2009; Tokur, 2011; Sevindik, 2015 tarafindan yapilan araştırmalarda yaşın ilerlemesiyle doğru orantılı şekilde dindarlık puanlarının arttığı sonuçlarına ulaşılırken; Şengül,2007; Ceviz,2009; Çakır, 2015; Özkan,2016; Yakut, 2016, Yılmaz,2019 tarafından yapılan araştırmalarda ise yaşın dindarlık üzerinde farklılık oluşturmadığı sonuçlarına ulaşılmıştır. Araştırmamızın yaşın ilerlemesine bağlı olarak dindarlık puanlarının artması ancak farkın anlamlı bulunmaması sonucu literatürle örtüşmektedir. Yaşın ilerlemesine bağlı olarak ömrün tükenmekte olduğu düşüncesinin daha yoğun olarak zihinleri meşgul etmesi ve bu durumun insanı diğer yaş 
gruplarında olduğundan daha fazla endişeye sevk etmesi (Hökelekli,1991) söz konusudur. Yaşlanmaya bağlı olarak insanda problemlerin aşılmasında dini bir başa çıkma unsuru olarak kullanma sıklığı artmaktadır (Şentepe,2015). Bu durum yaşın ilerlemesine bağlı olarak dindarlık puanlarının yükselmesini açıklamaktadır. Ancak yaş değişkenine bağlı olarak ortaya çıkan farkın anlamlı bulunmaması ise dindarlı̆̆ı etkileyen bir faktör olarak yaşın kabul edilebildiği ancak yaşın çok boyutlu bir olgu olarak dindarlığ etkileme ve değiştirme potansiyelinin yeterli düzeyde olmadığı şeklinde değerlendirilebilir.

\section{Meslek - Mevsimsellik ve Dindarlk İlişkisi}

Meslek - Mevsimsellik: Meslek değişkenine göre en yüksek mevsimsellik puanına üniversite öğrencilerinin sahip olduğu ancak meslekler arası oluşan mevsimsellik puan farkının istatistiksel açıdan anlamlı olmadığı görülmektedir ( $f(3.382 ; p=0,58 ; p>0,05)$. Diğer bir ifade ile meslek değişkeni mevsimsellik üzerinde anlamlı fark oluşturacak bir etkiye sahip değildir. Öznesi insan olan ve insanı etkileyen her şeyden etkilenmesi kaçınılmaz olan mesleklerin mevsimsel özelliklerden de doğrudan veya dolaylı olarak etkilenmemeleri düşünülemez. Araştırmada örneklemin meslek çeşitliliğinin sınırlı tutulması ve mevsimsellikten direkt etkilenme potansiyeli bulunan ulaşım, tarım, turizm vb. sektörlerle ilgili mesleklere yer verilmemesi bir araştırmada sinırlılık olarak değerlendirilebilir. Ancak bu dört meslek grubunun verilerinin sonucuna göre meslek değişkeninin mevsimsellik üzerinde anlaml-lık düzeyinde fark oluşturacak güçte bulunmadığını söylemek mümkündür.

Meslek - Dindarlık: Meslek değişkeni ile dindarlık karşılaştırmasına baktığımızda ise en yüksek dindarlık puanına esnafların sahip olduğu ancak oluşan farkın anlamlı olmadığ1 görülmektedir (f (5.438; p=0,68; p>0,05). Konuyla ilgili (Ayten, 2009; Özcan, 2007; Güven 2019; Gezenler,2019, Sevindik,2015; Tellioğlu,2015; İnce,2019) tarafından yapılan araştırmalarda meslek değişkeninin dindarlık üzerinde anlamlı fark oluşturduğu tespit edilmiştir. Aydemir (2008) ise yaptığı araştırmada bizim araştırma sonucumuzla örtüşür şekilde meslek değişkeninin dindarlık üzerinde anlamlı fark oluşturmadığı bulgusuna ulaşmıştır. Literatürdeki bu çeşitliliğin nedeni olarak 
araştırmaların örneklemlerindeki meslek çeşitliliğini ve aynı meslekten olunsa bile meslek şartlarının ve durumlarının farklılığını görmek gerekir. Her insan hayatını devam ettirebilmek ve sorumlu olduğu aile bireylerinin temel ihtiyaçların karşılayabilmek için bir gelire ihtiyaç duyar ki bu gelir meslekle ilişkilendirilen bir konudur. İnsanların meslek sahibi olması uzunca bir süreci gerektirir. Dolayısıyla meslekler insani unsurlardan bağımsız nötr bir değişken olarak değil, aile, eğitim, çevre koşulları, kültür, din gibi insan üzerinde üst düzey etkileme potansiyeli bulunan faktörler bağlamında değerlendirilmelidir.

\section{Genel Mevsimsellik ve Genel Dindarlk Düzeyleri}

Genel Mevsimsellik Düzeyi: Mevsimsellik puan ortalamasının likert tipi ölçekte en yüksek puan olan 4 üzerinden ılımlı (2) ile belirgin (3) aşamaları arasında orta düzeyde olduğu $(X=2.62)$ görülmektedir. İnsan üzerinde biyolojik, fizyolojik, duygusal ve psikolojik etkilerinden söz edebileceğimiz mevsimselliğin biyolojik ve fizyolojik etkileri genel olarak modern çağın teknolojik ve tıp alanındaki gelişmelerine bağlı olarak tolere edilebilmekle birlikte psikolojik ve duygusal etkileri konusunda insanoğlu aynı şansa sahip değildir. Bu bağlamda genel mevsimsellik puanının orta düzeyde bulunmasını, örneklemin özellikleri (erkek ve genç ağırlıklı olması) ve araştırmanın sınırlılıkları (mevsimsellikten direkt ilişkilendirilebilecek mesleğe yer verilmemesi) göz önünde bulundurulduğunda yükselme riskinin kuvvetli olduğu bir sonuç olarak değerlendirmek mümkündür.

Genel Dindarlık Düzeyi: Dindarlık ölçeği ortalamasının likert tipi ölçekte en yüksek puan 5 üzerinden katılıyorum (4) ifadesine daha yakın olduğu yani orta düzeyin üzerinde yüksek düzeye yakın $(X=3.81)$ olduğu söylenilebilir. Ayrıca dindarlık boyutlarının ortalama puanlarına bakıldığında örneklemin en yüksek ortalamaya duygu boyutunda, en düşük ortalamaya ise ibadet boyutunda sahip olduğu görülmektedir. Bu durum katılımcların genel dindarlık puanlarının yüksekliğini sağlayan faktörün, ibadetlerin yerine getirilmesi boyutundan ziyade dine duygusal bağllık olduğunu bizlere göstermektedir. Dolayısıyla bu sonuç bizlere insanın dine duygusal anlamda yüksek düzeyde bağlılık göstermesine karşın ayn bağlılığı dinle ilgili uygulamalar ve ritüeller konusunda göstermediğini göstermektedir. 


\section{Sonuç ve Öneriler}

İnsan doğum öncesinden başlayan ve tüm yaşamı boyunca çeşitli evreler halinde gelişimini sürdüren bir varlıktır. Bu süreç insanın cinsiyeti, yaşı, çevresel koşulları, ailesi, eğitimi, yaşadığı coğrafyanın özellikleri, biyolojik ve fizyolojik potansiyeli gibi çok zengin bir yelpazede değerlendirilen bir husustur. Olumlu olarak algıladığı bir yaşantı, yaşamının tüm boyutlarında olumlu karşılık bulabileceği gibi olumsuz olarak algiladığı bir yaşantı da onun yaşamının psiko-sosyal, duygusal ve fizyolojik boyutlarında olumsuz karşılık bulacağı bir gerçekliktir. İnsanın gelişim sürecini sağlıklı bir şekilde sürdürebilmesi, çok boyutlu yapısına yönelik risk barındıran ve yüzleşmek zorunda kaldığı problemlerinin üstesinden gelebilmesiyle mümkün olacaktır. Bu bağlamda mevsimsellik olarak anlamlandırılan mevsimlerin biyolojik, fizyolojik ve psikolojik etkilerinin de değerlendirilmesi söz konusudur. Mevsimsellik ile yine insanın yaşamında önemli bir karşllığı bulunan dindarlık olgusunu inceleme ve aralarında ne tür bir ilişki olduğunu anlama çabasının bir ürünü olan araştırmamız alanında bir ilk olma özelliği taşımaktadır. Örneklem bazında araştırmaya sınırlılık olarak yansıyan hususlara rağmen elde edilen verilerin alana önemli katkılar sağlaması beklenmektedir.

Mevsimsellik ile dindarlık ilişkisini anlama amacı taşıyan araştırmamızda "Kişisel Bilgi Formu”, "Mevsimsellik Ölçeği" ile "Dindarlık Envanteri" kullanılarak elde edilen verilerin SPSS programında frekans, aritmetik ortalama, standart sapma; çarpıklık ve basıklık değerlerinin normal dağılım puan aralığında olması üzerine parametrik testlerden t-testi, Pearson korelasyon, Anova ve Scheffe testi anlamlılık düzeyi $\mathrm{p}<0,05$ kabul edilerek uygulanmış ve şu sonuçlara ulaşılmıştır:

1- Örneklemin mevsimsellik puanını orta düzeydedir. Dindarlık puanı ise yüksek düzeye yakın bir ortalamaya sahiptir.

2- Mevsimsellik ile dindarlığın duygu boyutu arasında anlamlı pozitif yönlü zayıf düzeyde ilişki tespit edilmiştir.

3- Yaş değişkeninin mevsimsellik puanları üzerinde oluşturduğu fark ise istatistiksel açıdan anlamlı bulunmuştur.

4- Mevsimsellik ile dindarlığın karşılaştırıldığı diğer değişkenler arasında anlamlı farklılık söz konusu değildir. 
Araştırmamızda mevsimsellik ile dindarlık arasındaki bulunan anlamlı pozitif yönlü zayıf ilişki ve yaş değişkeninin mevsimsellik puanları üzerinde oluşturduğu anlamlı fark sonuçlarına bağlı olarak şu önerilerde bulunulmuştur:

1- Sağlıklı bir yaşlılık süreci için mevsimsellik ile bireysel potansiyelin etkileşimi araştırılmalı ve çıan sonuçlar göz önünde bulundurularak mevsimselliğe bağlı biyolojik, fizyolojik, duygusal ve psikolojik riskler önceden tespit edilmeli ve de konuyla ilgili bireysel bazda ve devlet bazında gerekli önlemler alınmalıdır

2- Hayatın istenilen bir formda sürdürülebilmesi için önyargısız şekilde din ve dindarlı̆̆ın birikimlerinden istifade edilmeli ve sağlayacakları katkılar göz ardı edilmemelidir. 


\title{
EXTENDED ABSTRACT
}

\section{Relationship Between Seasonality And Piety}

\author{
Selahattin Yakut \\ Yozgat Bozok University
}

\begin{abstract}
A human being is an entity that starts before birth and continues its development in various stages throughout its entire life. This process is evaluated in a very rich range of subjects such as gender, age, environmental conditions, family, education, characteristics of the geography in which he lives, biological and physiological potential. Characteristics inherited on human beings and their gains as a result of their interaction with the environment play an important role in the construction of its psychosocial structure. Although it is not a robot driven by human heritability, it is also not entirely independent of the traits transmitted to it by genes. All of these factors not only affect his physiological development, but also make him feel in shaping his psychological and emotional world. One of the main issues affecting the psychosocial world of man in this process is the human activity of making sense of environmental stimuli. People tend to place meaning in everything around them. This is one of his most characteristic features. A life that he perceives positively and places a positive meaning is a reality in which he can find a positive and positive response in all dimensions of his life, as well as a life in which he finds a negative and negative response in the psycho-social, emotional and physiological dimensions of his life. It will be possible for the human to continue the development process in a healthy way by overcoming the problems that pose a risk to his multidimensional structure and which he has to face. In this context, the biological, physiological and psychological effects of the seasonality meaning seasons are also evaluated. Because the seasons primarily affect the physiological structure of human beings, but also have the potential to affect the psychological and emotional structure of human beings. Because the human organism is in a state of integrity. Just as physical factors are equivalent in his spiritual world, factors in his spiritual world are reflected in his bodily features. A person with a physical illness is also at great risk for psychological health. In the
\end{abstract}


same way, this situation of a person experiencing problems in the spiritual world shows itself as a great possibility of negatively affecting his physical structure. In this context, the seasons affect both the physiological structures and the psychosocial structures of humans. Especially in the context of climate diversity, it is important to understand the nature and character structures of humans. It has been reported that people living in the regions where the warm climate prevails have a warmer structure in human relations and exhibit friendlier behavior.

Religion and religiosity are accepted as one of the phenomena that are active in the psychosocial world of man. It is also possible to say that religiousness, which we can refer to as the reflection of religion and religion on life, has a counterpart in the spiritual worlds of people, as well as the socialization of people who depend on them with rituals, physical health with hygiene and cleanliness principles, and psychological health with morale principles. In the studies conducted, the linking of religiousness with the factors that have the potential to directly affect his happiness, such as subjective well-being, psychological well-being, psychological health, empathy, psychological resilience, life satisfaction, and positive thinking supports this idea. In this context, the study of the phenomenon of religiosity, which has an important equivalent in the life of seasonality, has an important contribution to the efforts of social sciences to understand people. Because with an understanding that excludes and ignores the religion and religiosity of human, the effort to understand the human will not yield healthy results. Therefore, our research, which is a product of the effort to examine the phenomenon of seasonality and religiosity and to understand what kind of relationship between them, is a first in the field. Despite the issues that are limited to the research such as the number of samples and the low number of professions, the data obtained from our research are expected to make significant contributions to the field and to provide different perspectives to the future researches.

In our research aiming to understand the relationship between seasonality and religiosity, frequency, arithmetic mean, standard deviation in the SPSS program of the data obtained by using "Personal Information Form", "Seasonality Scale" and "Religiosity Inventory"; As the skewness and kurtosis values are within the normal distribution score range, t-test, Pear- 
son correlation, Anova and Scheffe test were applied by accepting the significance level $\mathrm{p}<0.05$ and the following results were achieved:

1. The seasonality score of the participants is intermediate. The religiosity score has an average near high level.

2. There was a poor level of significant positive correlation between seasonality and the emotion dimension of piety. In other words, seasonal characteristics correspond to the feeling dimension of piety.

3. The difference between age and seasonality scores was found to be statistically significant. In other words, older individuals are most affected by seasonal characteristics.

4. There is no significant difference between other variables in which seasonality and religiousness are compared. In other words, the difference created by gender and occupational variables on seasonality and religiosity has not reached the level of statistical significance.

In our study, the following suggestions were made depending on the significant positive weak relationship between seasonality and religiosity and the meaningful difference results of the age variable on seasonality scores:

1. For a healthy old age process, the relationship between seasonality and heredity and environmental interaction should be investigated, and considering the outcomes, the biological, physiological, emotional and psychological risks related to seasonality should be determined in advance and necessary measures should be taken on an individual and state basis.

2. In order to sustain life in a desired form, the accumulation of religion and religiosity should be used without prejudice and their contributions should not be ignored.

\section{Kaynakça / References}

Acar, M. C. (2019). Öz güven ile dindarlık arasındaki ilişki: Üniversite öğrencileri üzerine bir araştırma. Bingöl Üniversitesi Illahiyat Fakültesi Dergisi, 14, 64-78.

Ahbap, B. Ö. (2014). Renklerin pazarlama üzerindeki etkisi. Yayınlanmamış yüksek lisans tezi, İstanbul Kültür Üniversitesi Sosyal Bilimler Enstitüsü, İstanbul.

Akın, G. (2014). İnsan sağlığı ve çevre etkileşimi, Ankara Üniversitesi Dil ve TarihCoğrafya Fakültesi Dergisi,54 (1), 105-116. 
Altun, R. (2015). Üniversite öğrencilerinde dindarlı ve narsisizm ilişkisi (Sinop örneği). Yayınlanmamış doktora tezi, Ondokuz Mayıs Üniversitesi Sosyal Bilimler Enstitüsü, Samsun.

American Psychiatric Association. (2013). DSM 5. American Psychiatric Association.

Ann, Na. (2002). Ruhsal renginiz ve hayatınızın anlamı. (Çev.A. Kesçi). İstanbul:Ötesi Yayıncilik

Atalar, A. (2012). Tıp fakültesi öğrencilerinde mevsimsel duygudurum bozukluğu. Uzmanlık tezi) Trakya Üniversitesi Tıp Fakültesi. Edirne.

Atalay, T. (2005). Illköğretim ve liselerde dindarlık. İstanbul: DEM.

Aydemir, B. ve Şenerol, H. (2014). İklim değişikliği ve türkiye turizmine etkileri: delfi anket yöntemiyle yapılan bir uygulama çalışması. Balıesir Üniversitesi Sosyal Bilimler Enstitüsü Dergisi, 17(31), 381-416.

Aydemir, R. E. (2008). Dindarlık ve mutluluk ilişkisi (ilk yetişkinlik dönemi, (Yayınlanmamış yüksek lisans tezi), Ondokuzmayıs Üniversitesi, Samsun.

Aydın, C. (2019). Dindarlık ile bilinçli farkındalık arasındaki ilişkinin incelenmesi. Ondokuz Mayıs Üniversitesi İlahiyat Fakültesi Dergisi. 47, 241 - 269.

Ayten, A. (2009). Prososyal davranışlarda dindarlık ve empatinin rolü. Yayımlanmamış doktora tezi. Marmara Üniversitesi, İstanbul.

Ayten, A. (2013). Din ve sağlık: bireysel dindarlık, sağlık davranışları ve hayat memnuniyeti ilişkisi üzerine bir araştırma. Dinbilimleri Akademik Araştırma Dergisi, 13(3), 7-31.

Bakım, B., Karaahmet, E., Altınbaş, K. ve Oral, T. (2013). Winter sale on lithium levels: The impact of seasonality. Bulletin of Clinical Psychopharmacology, 23(4), 315-319.

Baynal, Fatma (2015). Yetişkinlerde dindarlık ve ruh sağlığı. İnsan ve Toplum Bilimleri Araştırmaları Dergisi.4(1), 206 - 231.

Bayraç, H. N. ve Doğan, E. (2016). Türkiye'de iklim değişikliğinin tarım sektörü üzerine etkileri. Eskişehir Osmangazi Üniversitesi İ̈BF Dergisi,11(1), 23- 48.

Belhi, E. Z. A. (2018). Beden ve ruh să̆ğğı, (Çev. M. Uysal). İstanbul: Endülüs Kitap.

Bovet, P. (1958). Din duygusu ve çocuk psikolojisi, Ankara: Türk Tarih Kurumu Yayınevi.

Certel, H. (2010/1). Dini yaşantıda kalite sorunu. SDü İlahiyat Fakültesi Dergisi, 24, 33-59.

Ceviz, F., H. (2009). Orta yaş ve yaşlilıta dindarlık, mistik tecrübe ve benlik saygısı.Yayımlanmamış yüksek lisans tezi. Marmara Üniversitesi Sosyal Bilimler Enstitüsü. İstanbul. 
Çakır, B. (2015). Ortaokul öğretmenlerinin dindarlık düzeyleri ile empatik eğilim düzeylerinin bazı değişkenler açısından incelenmesi: Ünye örneği.Yayımlanmamış yüksek lisans tezi. Ondokuz Mayıs Üniversitesi, Samsun.

Çekal, N. (2006). Huzurevlerinde kalan yaşlıların beslenme servisi örgütünden memnuniyet durumları, Aile ve Toplum Dergisi, 3(10).

Çetin, Ensar, Dil, Kemal Dil, Yazıcı, Sedat ve Arslan,, Hakan (2019). Aktif yurttaşlık ile dindarlık durumu arasındaki ilişkinin sosyolojik açıdan incelenmesi. IBAD Sosyal Bilimler Dergisi, 172-184. 184 DOI: 10.21733/ibad.610828.

Dağdeviren, H. N. (1996). Bipolar duygudurum bozukluklarinda mevsimsellik ve mevsimsel duygudurum bozukluğu. Tipta Uzmanlık Tezi. Sağlık Bakanllğı İstanbul Şişli Etfal Eğt. ve Arş. Hastanesi, İstanbul.

Dağlı, E., N. (2010). Yaşllarda ölüm kagısı ve dindarllk. Yayımlanmamış yüksek lisans tezi. Selçuk Üniversitesi Sosyal Bilimler Enstitüsü. Konya.

Doğan Çalışkan, Z., Kurt, Ü. ve Timur, M. C. (2017). İklim değişikliği ve ulaşım sektörü ilişkisinin ekonometrik analizi: Türkiye Örneği.ENSCON, İnternational Congress of Energy, Economy and Policy, Proceedings Book 25-26 March, İstanbul, Turkey. 1-10.

Ekinci, M.,Okanlı, A. ve Gözüağca, D. (2005). 'Mevsimsel depresyonlar ve baş etme yolları'. Anadolu Hemşirelik ve Sağhlk Bilimleri Dergisi.8(1), 109-112.

Elmas, H., E. (2017). Ortaöğretim öğrencilerinin dindarlı eğilimlerinin bazı kişilik özellikleri ile ilişkisinin incelenmesi. Yayımlanmamış doktora tezi. Gazi Üniversitesi Sosyal Bilimler Enstitüsü. Ankara.

Erkol, M. (2015). Türkiye'de dini hayatı anlamlandırmak: dindarlık olgusu ve dindarlığın ölçülmesi. Afyon Kocatepe Üniversitesi Sosyal Bilimler Dergisi. 17(2), 131-161.

Gencer, N. (2019). Dindarlık ve öznel iyi oluş: uluslararası bir bakış. din ve bilim Muş Alparslan Üniversitesi İslami İlimler Fakültesi Dergisi. 2(1), 97-114.

George, D. Ve Mallery, P. (2010). SPSS for windows step by step: A simple guide and reference 17.0 update (10th Edition). Boston: Pearson, 2-85.

Glock, C.Y. (1998). Dindarlı̆̆ı boyutlar üzerine, (Çev. M. Emin Köktaş), Din Sosyoloji, (Der.) Yasin Aktay-M. Emin Köktaş, İstanbul: Vadi Yayınları.

Gürsu, O. (2011). Ergenlik döneminde psikolojik sağllk ve dindarlik ilişkisi.Yayınlanmamış yüksek lisans tezi. Selçuk Üniversitesi Sosyal Bilimler Enstitüsü.Konya.

Hamer, D. ve Copeland, P. (1999). Genlerimizle yaşamak. İstanbul: Evrim Yayınları. 
Han, Ling vd. (2000).Seasonal variations in mood and behavior among Chinese medical students. American Journal of Psychiatry 157, 133-135.

Hökelekli, H. (2003). Din psikolojisi. Ankara: Türkiye Diyanet Vakfı Yayınları.

Hökelekli, H. (1991). Ölüm ve ölüm ötesi psikolojisi. Uludă̆ Üniversitesi İlahiyat Fakültesi Dergisi,3(3), 151-165.

Hökelekli, H. (1998). Din psikolojisi, 3.Basım, Ankara:TDV Yayınları.

Kandemir, F. (2016). Umut-iyimserlik ve dindarlık ilişkisi. Yayınlanmamış Doktora Tezi. Atatürk Üniversitesi Sosyal Bilimler Enstitüsü, Erzurum.

Karaca, F. (2000). Ölüm psikolojisi. İstanbul: Beyan Yayınları.

Karasar, N. (2009). Bilimsel araştırma yöntemi. Ankara: Nobel Yayıncllk.

Karslı, N. (2019). Psikolojik iyi oluş ve dindarlık ilişkisi: Trabzon ilahiyat örneği. Recep Tayyip Erdoğan Üniversitesi İlahiyat Fakültesi Dergisi, 15, 173-205

Kartopu, S. ve Başkonuş, L. (2019). Ergen suçluluğu ve dindarlık lise örneklemi üzerinde bir araştırma. Gümüşhane Üniversitesi İlahiyat Fakültesi Dergisi,8(16),185-217.

Kılıç, Selim (2018).SPSS uygulama görüntüleri eşliğinde istatistik çözümlemeleri. İstanbul: Nobel Tip Kitabevleri.

Kımter, N (2011). Üniversiteli gençlerde dindarlık ile benlik saygısı arasındaki ilişki üzerine bir araştırma. Çankır Karatekin Üniversitesi Sosyal Bilimler Enstitüsü Dergisi. 2(2) , 39 - 60.

Kiremitçi Canıöz, E. ve Coşkun, H. (2018). Üniversite öğrencilerinin mevsimsellik ve öznel iyi oluş düzeyleri arasındaki ilişkide depresyon ve anksiyetenin aracı rolü. Kalem Eğitim ve İnsan Bilimleri Dergisi , 8(2), 419-439, doi:10.23863/kalem.2019.110

Kiremitçi, E. (2016). Üniversite öğrencilerinde mevsimsellik ve öznel iyi oluş ilişkisinin psikolojik semptomlara göre incelenmesi. Yayınlanmamış Yüksek Lisans Tezi. Abant İzzet Baysal Üniversitesi Sosyal Bilimler Enstitüsü. Bolu

Kline, R. B.(2011). Principles and practice of structural equation modeling ( third edition). New York: The Gouilford Press.

Koç, M. (2009). Dindarlık ile benlik saygısı arasındaki ilişki: yetişkinler üzerine ampirik bir araştırma. Uludă̆ Üniversitesi İlahiyat Fakültesi Dergisi. 18(1), 473 - 493.

Köktaş, M. E. (1993). Türkiye' de dinî hayat, İzmir örneği. İstanbul: İşaret Yayınları. Kula, N. (2001). Kimlik ve din. İstanbul: Ayışığı Kitapları.

Kurt, A. (2009). Dindarlığı etkileyen faktörler. Uludă̆ Üniversitesi İlahiyat Fakültesi Dergisi.18 (2) 1-26. 
Kutlu, R. (2018). Çevresel faktörlerin mekan kalitesi ve insan sağlığına etkileri. The Turkish Online Journal of Design, Art and Communication - TOJDAC,8(1), 67-78.ISSN: 2146-5193,

Mehmedoğlu, A. U. (2004). Kişilik ve din, 1. Basım, İstanbul: Dem Yayınları.

Mehmedoğlu, Y.(2004). Ahlak ve dini gelişim, çocuğum değerlerini öğreniyor, İstanbul: Morpa Kültür Yayınları.

Noyan, M. A., Elbi, H. ve Korukoğlu, S. (2000). Mevsimsel gidiş değerlendirme formu (MGDF): Güvenilirlik araştırması. Anadolu Psikiyatri Dergisi, 1(2), 69-77.

Okyayuz, Ü. H. (1999). Sağlık Psikolojisi. Ed. Ü. H. Okyayuz, Ankara: Türk Psikologlar Derneği Yayınları.

Öğük, E. (2019). Dindarlık algıları ve şiddet. Gaziosmanpaşa Üniversitesi İlahiyat Fakültesi Dergisi.7(1) , 1 - 30.

Özcan, Z. (2016). Empati ve dindarlık arasındaki ilişki. Insan ve Toplum Bilimleri Araştırmaları Dergisi. 5(8), 2758 - 2781.

Özdamar, K. (2002). Paket programlarla istatiksel veri analizi -1. Eskişehir: Kaan Kitapevi.

Özdemir, Y. Z. (2018). Bipolar bozuklukta mevsimsellik ve klinik özellikler ile ilişkisi. Tıpta Uzmanlık Tezi. Ege Üniversitesi Tıp Fakültesi Psikiyatri Anabilim Dalı. İzmir.

Özgüner, H. (2004). Doğal Peyzajın İnsanların Psikolojik Ve Fiziksel Sağlığı Üzerine Etkileri. Süleyman Demirel Üniversitesi Orman Fakültesi Dergisi,2, 97-107. Seri: ISSN: 1302-7085..

Özkan, O. (2016). Öfke kontrolü ve dindarlık ilişkisi. Yayımlanmamış yüksek lisans tezi. Süleyman Demirel Üniversitesi Sosyal Bilimler Enstitüsü. Isparta.

Öztürk, Latif M., İsa, G. ve Y1lmaz, S. S. (2017). Lisans öğrencilerinin mutluluk ve dindarlık ilişkisi: Kırıkkale Üniversitesi örneği. Akademik Yaklaşımlar Dergisi. 8(1), 23 - 39.

Pargament, K. I. (2005). Acı ve tatlı: Dindarlığın bedelleri ve faydaları üzerine bir değerlendirme. (Çev. A. U. Mehmedoğlu). Ç. Ü. İlahiyat Fakültesi Dergisi,5(1), 279-313.

Polat, Ö. ve Uslu, E. E. (2010). Türkiye'nin dış ticaret verilerinde mevsimsellik. Gaziantep Üniversitesi Sosyal Bilimler Dergisi.9(2)407-423.

Roecklein, K. A. ve Rohan, K. J. (2005). Seasonal affective disorder: An overview and update. Psychiatry (Edgmont).2(1), 20-26. 
Rosenthal, N. E., Sack, D. A., Gillin, J. C., Goodwin, F. K., Davenport, Y., Mueller, P.S., Newsome, D. A. ve Wehr, T. A. (1984). Seasonal affective disorder: A description of the syndrome and preliminary findings with light therapy. Archives of General Psychiatry, 41(1), 72-80.

Santrock, J. W. (2012). Yaşam boyu gelişim-gelişim psikolojisi, (Çev. G. Yüksel). Ankara:Nobel Akademik Yayınları.

Sevindik, D. (2015). Orta yaş dönemi bireylerde dindarlık-mutluluk ilişkisi (Denizli örneği).Yayımlanmamış yüksek lisans tezi. Süleyman Demirel Üniversitesi Sosyal Bilimler Enstitüsü. Isparta.

Simrén, M., Axelsson, J., Gillberg, R., Abrahamsson, H., Svedlund, J. ve Björnsson, E. S. (2002). Quality of life in inflammatory bowel disease in remission: The impact of IBS like symptoms and associated psychological factors. The American Journal of Gastroenterology. 97(2), 389-396.

Subaşı, N. (2001). Gündelik hayat ve dinsellik.Avrupa Günlüğ̈̈̈, 2, 237-260.

Şahin, A. (1999).Illahiyat, top ve mühendislik fakültelerinde okuyan öğrencilerde dini hayatın boyutları üzerine karşılaştırmalı bir araştırma Yayınlanmamış Doktora Tezi. Dokuz Eylül Üniversitesi Sosyal Bilimler Enstitüsü.İzmir.

Şengül, F. (2007). Dindarlık ve ruh sağhlğı ilişkisi. Yayımlanmamış yüksek lisans tezi. Marmara Üniversitesi Sosyal Bilimler Enstitüsü. İstanbul.

Şentepe, A. (2015). Yaşlılık döneminde dini başaçıkma. Insan Ve Toplum Bilimleri Araştırmaları Dergisi, 4(1), 186-205.

Şentürk, Ü. (2016). Yaşlılık: özellikler, davranışlar ve sorunlar.(). (Editör:M. Zencirkıran). içindeDavranış bilimleriİstanbul: Dora Yayınları.

Temiz, Y. E. (2019). Alçakgönüllülük, dindarlık, psikolojik iyi olma ve yaşam doyumu değişkenleri arasındaki ilişkinin incelenmesi. Yayınlanmamış Doktora Tezi. Sakarya Üniversitesi Sosyal Bilimler Enstitüsü. Sakarya.

Tokur, B. (2011). Stres-dindarlık ilişkisi üzerine bir araştırma. Yayımlanmamış doktora tezi. Atatürk Üniversitesi, Sosyal Bilimler Enstitüsü, Erzurum.

Yakut, S. (2016). Öğretmenlerde yabancılaşma, yalnızlık ve dindarlık ilişkisi: Polatı örneği. Yayımlanmamış doktora tezi. Süleyman Demirel Üniversitesi, Isparta.

Yapıcı, A. (2007). Ruh sağhı̆̆ı ve din: psiko-sosyal uyum ve dindarlık. Adana: Karahan.

Yapıcı, A. (2012). türk toplumunda cinsiyete göre dindarlık farklılaşması: bir meta analiz denemesi. Fırat Üniversitesi İlahiyat Fakültesi Dergisi, 12, 1-34.

Yıldız, M. (1998). Dini hayat ile ölüm kaygısı arasındaki ilişki üzerine bir araştırma. Yayınlanmamış Doktora Tezi. Dokuz Eylül Üniversitesi Sosyal Bilimler Enstitüsü, İzmir. 
Yıldız, M. (2001). Dindarlığın tanımı ve boyutları üzerine psikolojik bir çalışma. Tabula Rasa. ISSN:1302-8898 , 1, 19-42.

Yılmaz, F. (2019). Dindarlık ve hoşgörü ilişkisi (konya merkez ilçelerinde görev yapan ögrretmenler örneği). Yayınlanmamış Doktora Tezi. Necmettin Erbakan Üniversitesi Sosyal Bilimler Enstitüsü, Konya.

Yoğurtcu, F. (2009). Yetişkinlerde dindarlık ve ruh să̆hı̆̆ı. Yayımlanmamış yüksek lisans tezi. Sakarya Üniversitesi, Sakarya.

Yöney, T. H., Taybıllı, B. ve Göktepe, E. O. (1995). İstanbul'da üniversite öğrencilerinde ruhsal durum ve davranışlarda mevsimsellik. Düşünen Adam. 8(1), 38-42.

Yumuşak, Sedat ve Boz, Hakan (2013). The Effect of Seasonal Affective Disorder on the Employees in Accommodation Establishments. Ekonomik ve Sosyal Araştırmalar Dergisi. 9(2), 371-394.

Yüksel, B. N. (2019). Bağımlı kişilik yapısı ile dindarlık eğilimleri arasındaki ilişki üzerine nicel bir araştırma: Düzce üniversitesi örneği. Uluslararası Sosyal Bilimler Dergisi. 2,9-26.

\section{Kaynakça Bilgisi / Citation Information}

Yakut, S. (2020). Mevsimsellik ve dindarlık ilişkisi. OPUS-Uluslararası Toplum Araştırmaları Dergisi, 16(27), 370-396. DOI: 10.26466/opus.669291 